\title{
Antitumor efficacy of D2C7-(scdsFv)-PE38KDEL, a novel immunotoxin targeting EGFRwt and EGFRvIll, by convection-enhanced delivery in orthotopic brain tumor mouse models
}

\author{
Xuhui Bao ${ }^{1,2^{*}}$, Vidyalakshmi Chandramohan', Stephen $T$ Keir ${ }^{1}$, Charles N Pegram', Roger E McLendon', \\ Chien-Tsun Kuan ${ }^{1}$, Ira H Pastan ${ }^{3}$, Darell D Bigner ${ }^{1}$
}

From Society for Immunotherapy of Cancer 28th Annual Meeting

National Harbor, MD, USA. 8-10 November 2013

\section{Objective}

The epidermal growth factor receptor (EGFR) gene is most frequently amplified and overexpressed, along with its truncated mutant, EGFRvIII, in glioblastomas. We tested the antitumor efficacy of the recombinant immunotoxin, D2C7-(scdsFv)-PE38KDEL (D2C7-IT), which is reactive with a 55 -amino acid (AA) region present in the extracellular domain of both EGFRwt and EGFRvIII proteins (Figure 1), by convection-enhanced delivery (CED) in orthotopic brain tumor mouse models established with human glioblastoma xenograft cells.

\section{Methods}

Orthotopic brain tumor models were established by inoculating 43 (EGFRwt expressing glioma cell), D270MG (EGFRwt and EGFRvIII espressing glioma cells), and NR6M (EGFRvIII expressing fibroblast cells) intracranially in the immunocompromised mice. CED was achieved by inserting a cannula into the brain tumor site, which in turn was connected to a subcutaneous osmotic pump delivering the immunotoxin into the tumor microenvironment. The antitumor efficacy was evaluated by KaplanMeier survival analysis.

\section{Results}

In the orthotopic brain tumor models of 43 , NR6M, and D270MG, D2C7-IT therapy via CED significantly prolonged the median survival time (MST) of the treatment group by about 1 month $(\mathrm{P}=0.0010), 1$ week $(\mathrm{P}=0.0074)$, and over 1 month $(\mathrm{P}=0.0061)$, respectively, compared with that of vehicle or negative control groups (Table 1 , Figure 1).

\section{Conclusion}

In the orthotopic brain tumor mouse models, the D2C7IT therapy via CED exhibited a robust therapeutic potential in treating brain tumors expressing EGFRwt, EGFRvIII, and both EGFRwt and EGFRvIII.

\section{Authors' details \\ ${ }^{1}$ Pathology, Preston Robert Tisch Brain Tumor Center, Durham, NC, USA. \\ ${ }^{2}$ Neurosurgery, Huashan Hospital, Fudan University, Shanghai, China. \\ ${ }^{3}$ Laboratory of Molecular Biology, Center for Cancer Research, National \\ Cancer Institute, National Institutes of Health, Bethesda, MD, USA.}


43

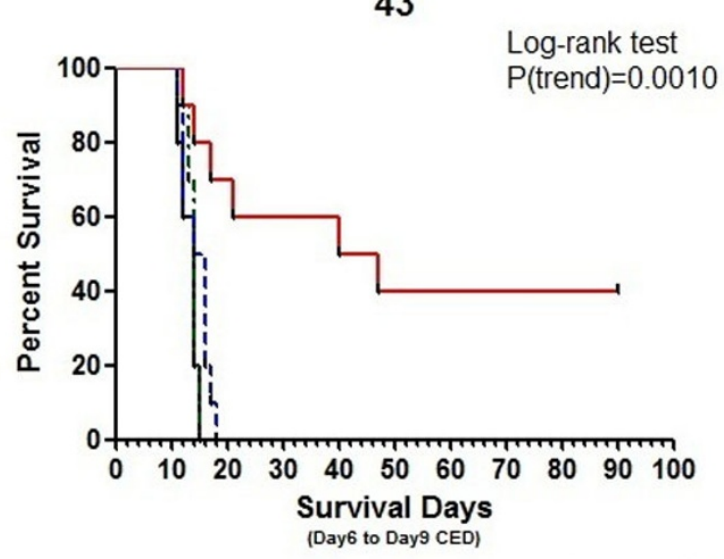

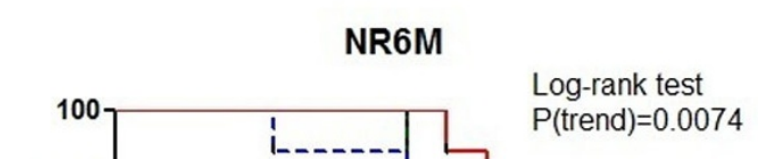

$\mathrm{P}($ trend $)=0.0074$

- Sham $-1-$ - 0.2\%HSA-PBS(Vehicle)

- +- P588-(scdsFv)-PE38KDEL(P588) $\rightarrow$ D2C7-(scdsFv)-PE38KDEL(D2C7)
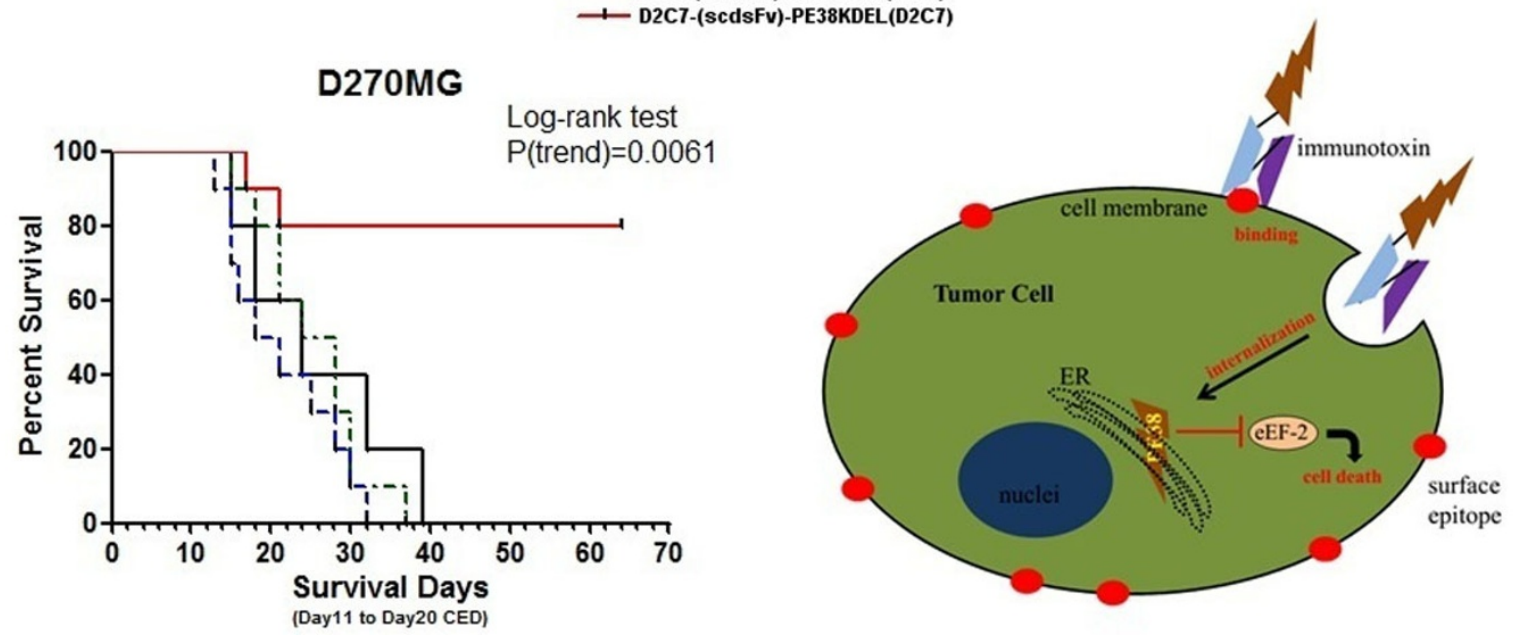

Figure 1 Kaplan-Meier survival curves of different brain tumor models and the immunotoxin killing paradigm

Table 1 Comparison of MST among different groups in three xenograft mouse models

\begin{tabular}{ccccc}
\hline (Day) & Vehicle & P588 & D2C7 & Log-rank test \\
\hline 43 MST & 14 & 15 & $43.5^{*}$ & 0.0010 \\
NR6M MST & 25 & 25 & 32 & 0.0074 \\
D270MG MST & 26 & 19.5 & $64^{* *}$ & 0.0061 \\
\hline
\end{tabular}

*Last 4 mice were euthanized on Day 90;

**Last 8 mice were euthanized on Day 64.

Published: 7 November 2013

doi:10.1186/2051-1426-1-S1-P126

Cite this article as: Bao et al:: Antitumor efficacy of D2C7-(scdsFv)-

PE38KDEL, a novel immunotoxin targeting EGFRwt and EGFRvIll, by

convection-enhanced delivery in orthotopic brain tumor mouse models.

Journal for ImmunoTherapy of Cancer 2013 1(Suppl 1):P126.

Submit your next manuscript to BioMed Central and take full advantage of:

- Convenient online submission

- Thorough peer review

- No space constraints or color figure charges

- Immediate publication on acceptance

- Inclusion in PubMed, CAS, Scopus and Google Scholar

- Research which is freely available for redistribution 